\title{
JURNAL AKUNTANS!

\section{PERSEPSI AKADEMISI DAN PRAKTISI TERHADAP OPINI HASIL PEMERIKSAAN AUDIT LAPORAN KEUANGAN PADA LEMBAGA PEMERINTAHAN DI INDONESIA}

\section{The Perceptions of Academision and Practitioner about Opinion Audit Result from Financial Statement on Government Institution in Indonesia}

\author{
Bunga Aulia $^{1)}$, RikaHenda Safitri ${ }^{2)}$ dan Rina Tjandrakirana ${ }^{3)}$ \\ Fakultas Ekonomi Universitas Sriwijaya, Sumatera Selatan ${ }^{1,2,3)}$
}

\begin{abstract}
In this paper want to explain perception of academics and practitioners as measured by several indicators, namely: (1) Understanding the quality of government financial statements, (2) Professional responsibility, (3) Integrity, and (4) Objectivity. The theories used in this study are Attribution Theory, Perception Theory, and Brunswik Theory Model. The population in this study are academics with status as lecturers in the city of Palembang, and practitioners namely accountants, auditors, consultants, civil servants, and others. The sample used in this study was 110 respondents using the cluster sampling method. This study uses quantitative methods. The data in this study were obtained primarily through a questionnaire. The data analysis technique used is an analysis of the T-Test or a different test. The results of this study indicate that (1) There is no difference in understanding the quality of government financial reports between academics and practitioners. (2) There are differences in the understanding of professional responsibility between academics and practitioners. (3) There is no difference in understanding the integrity of the auditor between academics and practitioners. (4) There is no difference in understanding of the objectivity of auditors between academics and practitioners.

Key words:Government financial statements, professional responsibility, understanding of integrity, understanding of objectivity.
\end{abstract}

\begin{abstract}
ABSTRAK
Penelitian ini bertujuan untuk menganalisis perbedaan persepsi akademisi dan praktisi yang diukur dengan beberapa indikator, yakni: (1) Pemahaman kualitas laporan keuangan pemerintahan, (2) Tanggung jawab profesi, (3) Integritas, dan (4) Objektivitas. Teori yang digunakan dalam penelitian ini adalah Teori Atribusi (Attribution Theory),Teori Persepsi (Perception Theory), dan Teori Brunswik's Lens Model. Populasi dalam penelitian ini adalah akademisi dengan status sebagai dosen di kota Palembang, dan praktisi yakni Akuntan, Auditor, Konsultan, PNS, dan lain-lain. Sampel yang digunakan pada penelitian ini sebanyak 110 responden dengan metode cluster sampling. Penelitian ini menggunakan metode kuantitatif.Data pada penelitian ini diperoleh secara primer melalui kuesioner. Teknik analisis data yang digunakan merupakan analisis uji T-Test atau uji beda. Hasil dari penelitian ini menunjukan bahwa (1) Tidak terdapat perbedaan Pemahaman kualitas laporan keuangan pemerintahan antara akademisi dan praktisi. (2) Terdapat perbedaan Pemahaman tanggung jawab profesi antara akademisi dan praktisi. (3) Tidak terdapat perbedaan Pemahaman integritas auditor antara akademisi dan praktisi. (4) Tidak terdapat perbedaan Pemahaman objektivitas auditor antara akademisi dan praktisi.
\end{abstract}

Kata kunci : Laporan keuangan pemerintahan, tanggung jawab profesi, Pemahaman integritas, Pemahaman objektivitas

Corresponding author: rikahenda@unsri.ac.id

Email addresses for author: unga6697@ gmail.com ${ }^{1)}$,rikahenda@unsri.ac.id ${ }^{2}$, rinatjandrakirana@yahoo.com ${ }^{3)}$ First submission received: 25 Juli 2019

Revised submission received: 14 September 2019

Accepted: 08 Oktober 2019 


\section{PENDAHULUAN}

Seiring dengan perkembangan ekonomi di Indonesia, pemerintah telah membuat beberapa perbaikan terkait regulasi kepada sektor pemerintah maupun swasta, terkhusus di bidang akuntansi untuk memudahkan para stakeholders yang berkepentingan dalam membuat keputusan. Dalam praktinya terdapat kecurangan ( $\mathrm{fraud}$ ) yang terjadi di beberapa perusahaan, skandal-skandal keuangan tersebut sebagai contoh Enron, WorldCom, Global Crossing, Qwest, Parmalatkarena telah membuat runtuh kepercayaan investor dan membuat disiplin ilmu baru yakni akuntansi forensik untuk mengatasi kecurangan(Husen, 2017).

Terbukti dengan diberlakukannya basis akrual pada laporan keuangan sektor pemerintahan sejak 2015 yang lalu (BPPK Kemenkeu). Pertanggung jawaban laporan keuangan pemerintah mengalami perubahan yang lebih baik yang mana dilihat dengan tiga aspek yakni partisipasi, transparansi, dan akuntabilitas (Safitri \& Aulia, 2017). Standar Akuntansi Pemerintahan (SAP) digunakan untuk menyajikan laporan keuangan pemerintah daerah (LKPD)(Setyaningrum \& Syafitri, 2012). Tahapan Reformasi keuangan yakni perencanaan dan penganggaran, pelaksanaan, serta pertanggungjawaban keuangan dan audit (Hilmi \& Martani, 2012).

Dalam penelitian Ardelean (2013) setelah kepercayaan dari pemangku kepentingan diubah, pemulihan kepercayaan tersebut menjadi prioritas profesi dan badan regulasi, karena kurangnya komitmen terhadap kepentingan publik dapat menyebabkan kesenjangan mengenai harapan publik dari audit. Menurut Lino \&Aquino (2017) Akhirnya, Chartered Accounting (CA) mulai menerbitkan pedoman mereka pada konvergensi Standar Akuntansi Sektor Publik Internasional (IPSAS), yang memberlakukan bagan akun standar dan penerapan kebijakan akuntansi tertentu oleh pemerintah kota. Akan tetapi, meskipun adanya kebijakan dalam penyusunan laporan keuangan pemerintah, banyaknya para karyawan yang masih kurang paham dan tidak berkompenten di bidang akuntansi. Tanggung jawab auditor memverifikasi laporan keuangan, yang mewakili posisi keuangan dan aktivitas yang dilakukan oleh entitas publik dan swasta (Gonzalo-Angulo \& Garvey, 2018).

Masyarakat secara umum belum mengetahui dan paham terkait opini auditor yang ditujukan kepada suatu lembaga atau pemerintahan atas dasar peniliaian laporan keuangan. Menurut Ramadhony \& Hadiprajitno (2014) masyarakat belum sepenuhnya memahami makna sebenarnya dari fungsi atestasi terutama dalam konteks opini "Wajar Tanpa Pengecualian" (WTP). Mereka percaya bahwa opini WTP menunjukkan bahwa laporan keuangan yang telah diaudit bebas dari kesalahan. Tata kelola pemerintah yang baik harus diterapkan oleh pemerintah daerah. Untuk dapat mengukur kemajuan pemerintah daerah, harus diterapkan evaluasi, monitoring, dan pengukuran kinerja yang sistematis(Marfiana \& Kurniasih, 2013).

Di Indonesia, dalam menjalankan tugasnya, standar auditing yang dibuat oleh Ikatan Akuntan Publik Indonesia (IAPI) sebagai pedoman auditor. Standar audit terdiri dari standar umum, standar kerja lapangan, dan standar pelaporan. Selain itu, akuntan publik juga harus mematuhi Kode Etik yang ditetapkan oleh Ikatan Akuntan Publik Indonesia (IAPI). Prinsipprinsip dasar etika profesional terdiri dari independensi, integritas, dan objektivitas (Rahmina \& Agoes, 2014).

Kegagalan audit yang terkait dengan skandal perusahaan permulaan abad ini, serta krisis keuangan global yang parah akhir-akhir ini, telah merusak citra publik profesi audit dan kepercayaan dalam fungsinya (Barrainkua \& Espinosa-Pike, 2018).Penelitian oleh (Wu, 2012) Audit dilihat sebagai bentuk tata kelola eksternal di mana tata kelola internal perusahaan yang efektif dapat menggantikan pada tingkat tertentu. Dalam penelitian Muhammad (2008) perlu mengetahui pemahaman para akuntan dan calon akuntan terkhusus pada wilayah Yogyakarta untuk menghadapi permasalahan etika bisnis yang akan dihadapi. 
Sedangkan dalam penelitian Dobre \& Turlea (2015) tinjauan ini adalah untuk memberikan nasihat tentang praktik tata kelola perusahaan untuk pemegang saham, investor atau badan nasional atau internasional lainnya yang menetapkan standar tertentu untuk memberikan opini. Menurut Cao, Li, \& Zhang, 2015 Karena mode audit di China tidak berubah sebagai respons spontan auditor terhadap risiko penipuan, tetapi alih-alih dimandatkan oleh pemerintah, penelitian ini menginvestigasi apakah auditor telah benar-benar berubah ke mode berbasis risiko dan sekarang mengevaluasi tata kelola perusahaan sebelum mereka mengonfigurasi efek audit mereka.

Penelitian oleh Liu \& Lin (2012) Audit pemerintah, tujuan mendasarnya adalah untuk memantau, memastikan dan menilai kemampuan pemerintah, merupakan pengaturan kelembagaan yang penting dalam pemerintahan modern pemerintahan. Dengan memantau operasi kekuasaan publik, terutama bagaimana sumber daya publik digunakan, audit pemerintah dapat memperkuat akuntabilitas dan mengurangi penyalahgunaan kekuasaan dan sumber daya. Tujuan dari makalah ini adalah untuk menyelidiki citra publik dari profesi auditor. Citra publik dari suatu profesi direpresentasikan oleh stereotipe (Navallas, del Campo, \& Camacho-Miñano, 2017). Sebagai contoh, 87 kementrian atau lembaga, 80 memperoleh opini WTP, 6 opini WDP, dan 2 tidak memberikan pendapat (TMP) yang merupakan hasil audit BPK RI tahun 2018 dari majalah tempo.

Contoh lainnya yakni dalam pemaparan Ikhtisar Hasil Pemeriksaan Semester (IHPS) BPK atas Laporan Keuangan Pemerintah Pusat (LKPP) 2017 disampaikan dalam sidang paripurna DPR di Gedung Nusantara II. Enam kementerian atau lembaga dengan opini Wajar Dengan Pengecualian (WDP) antara lain Kementerian Pertahanan, Kementerian Pemuda dan Olahraga (Kemenpora), Komisi Nasional Hak Asasi Manusia (Komnas HAM), Badan Pengawas Tenaga Nuklir (Bapeten), Televisi Republik Indonesia (TVRI), dan Radio Republik Indonesia (RRI). Sementara dua kementerian atau lembaga dengan opini TMP adalah Kementerian Kelautan dan Perikanan (KKP) serta Badan Keamanan Laut (Bakamla).Sementara dua kementerian atau lembaga dengan opini Tidak Memberikan Pendapat (TMP) adalah Kementerian Kelautan dan Perikanan (KKP) serta Badan Keamanan Laut (Bakamla). CNN Indonesia juga menyatakan Badan Pemeriksa Keuangan (BPK) tidak memberikan opini untuk Kementerian Kelautan dan Perikanan (KKP) untuk Laporan Keuangan Pemerintah Pusat (LKPP) Tahun 2017.

Kementerian yang dipimpin Susi Pudjiastuti itu menjadi satu-satunya kementerian/lembaga yang disematkan opini Tidak Memberikan Pendapat (TMP).Secara keseluruhan, BPK memeriksa 87 laporan keuangan kementerian/lembaga, serta satu laporan keuangan Bendahara Umum Negara.Sebanyak 80 entitas mendapatkan opini Wajar Tanpa Pengecualian (WTP), enam entitas Wajar Dengan Pengecualian (WDP), dan dua entitas didapuk TMP. Melalui laman website Merdeka juga mengatakan yang yang sama, sebagai informasi, tahun lalu, BPK juga memberi opini disclaimer untuk laporan keuangan tahun 2016 milik kementerian pimpinan Susi Pudjiastuti itu karena akuntabilitas yang tidak terpenuhi dalam laporan keuangan KKP terkait pengadaan kapal nelayan.

Penelitian ini menghimpun pandangan yang dikemukakan oleh kalangan akademisi (dosen akuntansi) maupun praktisi (akuntan, auditor, konsultan, PNS, dan lainnya) tentang (1) Pemahaman Kualitas Laporan Keuangan Pemerintahan, (2) Tanggung Jawab Profesi, (3) Integritas, (4) Objektivitas. Oleh karena nya, perlu diteliti pandangan/ persepsi kedua golongan tersebut(Iprianto, 2012).

Akademisi adalah suatu istilah umum bagi komunitas mahasiswa dan cendekiawan terlibat dalam pendidikan tinggi dan penelitian (Mulyanti, 2013). Oleh karena itu, tulisan ini akan menganalisis persepsi akademisi dan praktisi terhadap opini yang diberikan oleh Badan Pemeriksa Keuangan Republik Indoneisa (BPKRI) kepada lembaga pemerintahan dalam Ikhtisar Hasil Pemeriksaan Semester pada laman resmi BPK RI. 


\section{Teori Atribusi}

\section{KERANGKA TEORITIS DAN HIPOTESIS}

Attribution Theory merupakan teori yang mempelajari perilaku atau pandagan manusia mengenai adanya suatu event dan menjelaskan sebab akibat suatu peristiwa itu terjadi(Steers, 1988). Menurut Fritz Heider perilaku seseorang didasarkan pada dua aspek yakni pertama dari dalam diri manusia misalnya pengetahuan, dan faktor dari luar diri manusia misalnya lingkungan. Karena adanya rasa penasaran, maka dari itu manusia menjadi tertarik untuk mencari tahu sebab dan akibat suatu event(Hudayati, 2002).

Pada penelitian keprilakuan (behavioral) terdapat variabel locus of control.Variabel tersebut terdiri dari dua komponen yaitu internal locus of control dan external locus of control.Internal locus of control adalah suatu kepercayaan dari dalam diri manusia untuk memiliki kemampuan, keahlian, dan usaha yang dimiliki. Dilain pihak external locus of control adalah kepercayaan akan terdapat faktor lainnya yang mempengaruhi seseorang(Hudayati, 2002). Teori atribusi menjelaskan bagaimana perilaku seseorang dalam beritindak dalam mengambil sebuah keputusan karena setiap orang memeliki perilaku yang berbeda berbeda beda dan auditor di tuntut untuk memiliki kompetensi dalam melaksaakan tugas audit (Astuti \& Latrini, 2017).

\section{Ilmu Audit}

Ada beberapa pengertian dari Auditing yaitu dari Konrath (2002): "Auditing adalah proses yang terstruktur dan sistematis untuk mengevaluasi bukti mengenai kejadian yang bersifat financial maupun non-financial untuk diteruskan kepada pihak yang berkepentingan". Kemudian menurut Arens, Elder, \& Beasley (2012) "Audit adalah akumulasi dan evaluasi bukti tentang informasi untuk menentukan dan melaporkan tingkat korespondensi antara informasi dan kriteria yang ditetapkan. Audit harus dilakukan oleh orang yang kompeten dan independen”.

\section{StandarPemeriksaanKeuangan Negara}

Standar Pemeriksaan Keuangan Negara pedoman untuk melakukan pemeriksaan pengelolaan dan tanggung jawab keuangan negara. Standar tersebut diberi judul, nomor, dan tanggal efektif. Keuangan Negara adalah hak dan kewajiban negara dalam sisi financial yang digunakan untuk belanja dan pengeluaran negara agar meningkatkan perekonomian negara. Pengelolaan Keuangan Negara adalah kegiatan pejabat daerah dalam mengolala keuangan negara untuk kemakmuran rakyat.

\section{Opini Audit}

Opini audit adalah pernyataan auditor terhadap kewajaran laporan keuangan dari organisasi yang telah terpenuhi pemeriksaannya. Kewajaran ini menyangkut materialitas, posisi keuangan, dan arus kas (Unnisa, 2015). Menurut Sutedja (2003) opini audit tahun sebelumnya akan menjadi faktor pertimbangan penting bagi auditor untuk mengeluarkan kembali (re-audit) opini audit pada tahun berikutnya.

\section{Penelitian Terdahulu}

Dalam penelitian Husen (2017) Persepsi mahasiswa dan praktisi tentang keahlian akuntan forensik menunjukkan tanggapan yang positif hal tersebut terjadi karena mahasiswa memandang bahwa akuntan forensik sebagai profesi yang normatif dan wakil dari pemerintah untuk mengungkap kemungkinan risiko yang akan terjadi terhadap penyelenggaraan keuangan Negara dan praktisi memandang bahwa akuntan forensik tidak mutlak sebagai suatu yang normatif, tetapi sebagai suatu pertimbangan jabatan yang dijalankan berdasarkan tujuan 
pembuktian, dan kemungkinan bukti yang dikumpulkan memberikan kepastian akan temuan auditor.

Penelitian oleh Mulyanti (2013) mengenai persepsi akademisi terhadap akuntansi forensik yang menjadi referensi dan modifikasi untuk penelitian ini menganalisis bahwa terdapat perbedaan persepsi yang signifikan antara responden dari S-1 dan dosen dengan S-2 serta profesi akuntan mengenai akuntansi forensik dan audit forensik. Terdapat perbedaan persepsi yang signifikan antara kelompok responden S1 dan dosen dengan responden S2 dan profesi akuntansi tentang akuntansi forensik sangat berperan terhadap sebuah peluang karir yang menjanjikan di masa yang akan datang. Tidak terdapat perbedaan persepsi yang signifikan antara kelompok responden S1 dan dosen dengan responden S2 dan profesi akuntansi tentang sebagai alat untuk mempercepat pemberantasan korupsi dan tindak penanggulagan tindak penipuan.

\section{Hipotesis}

Menurut Thoyibatun, 2012 kecenderungan kecurangan akuntansi (KKA) ditandai dengan adanya tindakan dan kebijakan untuk menghilangkan atau penyembunyian informasi yang sebenarnya untuk tujuan manipulasi. Dapat disimpulkan bahwa terdapat perbedaan persepsi secara signifikan antara akademisi dan praktisi akuntansi tentang minat, relevansi, metode integrasi, pendidikan berkelanjutan, dan kompetensi akuntan forensik.Persepsi praktisi lebih tinggi dari pada akademisi tentang minat dan permintaan kedepan pendidikan akuntansi forensik.Praktisi juga lebih tinggi persepsinya dari pada akademisi tentang relevansi pendidikan akuntansi forensik. Akan tetapi, persepsi akademisi lebih tinggi dibanding praktisi tentang manfaat pendidikan akuntansi forensik (Putra, 2015)

Hipotesis dari penelitian ini yaitu hipotesis assosiatif/hubungan yang menanyakan hubungan antara dua variabel atau lebih (Sugiyono,2006).

Berdasarkan hasil penelitian di atas, maka hipotesis yang diajukan dalam penelitian ini adalah sebagai berikut:

$\mathrm{Ha}_{1}$ : Terdapat perbedaan persepsi akademisi dengan praktisi terhadap keahlian akuntan

$\mathrm{Ha}_{2}$ : Terdapat perbedaan persepsi akademisi dengan praktisi terhadap keahlian akuntan forensik tentang kemampuan berpikir kritis.n forensik tentang kemampuan analisis deduktif.

$\mathrm{Ha}_{3}$ : Terdapat perbedaan persepsi akademisi dengan praktisi terhadap keahlian akuntan forensik tentang kemampuan memecahkan masalah yang tidak terstruktur.

$\mathrm{Ha}_{4}$ : Terdapat perbedaan persepsi akademisi dengan praktisi terhadap keahlian akuntan forensik tentang kemampuan penyelidikan fleksibilitas.

\section{METODE PENELITIAN}

\section{Ruang Lingkup Penelitian}

Penelitian ini termasuk penelitian kuantitatif dengan tipe penelitian eksplanatori/ eksploratif.Tujuan penelitian ini yakni untuk menjelaskan secara empiris hubungan/ korelasi antar variabel.Hubungan tersebut dapat berbentuk korelasional, kausalitas (sebab akibat) (Nuryaman, Chirstine, 2015).Tujuan penelitian eksploratif untuk lebih dapat memahami masalah penelitian (Nuryaman, Chirstine, 2015).

\section{Jenis dan Sumber Data}

Penelitian ini akan menganalisis bagaimana persepsi masyarakat terhadap opini yang diberikan oleh Auditor (BPK) terhadap lembaga di Indonesia maka dari itu, obyek yang digunakan dalam penelitian ini adalah akademisi pada universitas di Palembang dengan 
cakupan tenaga pengajar (Dosen) yang dirasa memiliki pengetahuan luas mengenai permasalahan tersebut dan praktisi (masyarakat yang memiliki profesi dan keahlian di bidang tertentu) di Kota Palembang yang memiliki pengetahuan luas mengenai permasalahan tersebut.

\section{Teknik Pengumpulan Data}

Untuk melihat hubungan antara persepsi akademisi dan praktisi terhadap opini audit yang diberikan kepada lembaga pemerintahan di Indonesia, maka pihak peneliti melakukan survei dengan kuisioner dan mencari sumber-sumber literatur yang berkaitan dengan obyek penelitian. Dilanjutkan dengan teknik pemeriksaan data untuk keperluan pengecekan atau sebagai pembanding terhadap data yang diperoleh, yaitu pengecekan data yang dilakukan dengan cara mengecek data berupa kasus yang telah diperoleh melalui beberapa sumber.

\section{Populasi dan Sampel}

Populasi dalam penelitian ini adalah akademisi dan praktisi di kota Palembang. Populasi yang diambil yakni 150 responden, dengan menggunakan teknik cluster sampling.Cluster Sampling adalah teknik pengambilan sampel dengan pemilihan mengacu pada kelompok bukan pada individu. Cara ini baik sekali dilakukan apabila tidak terdapat atau sulit menentukan dan menemukan kerangka sampel meski dapat juga dilakukan pada populasi yang kerangka sampel sudah ada (Utama, 2016).

\section{HASIL DAN PEMBAHASAN}

\section{Analisis Statistik Deskriptif}

Statistik deskriftif memberikan gambaran atau deskripsi suatu yang dilihat dari kriteria nilai rata-rata (mean), standar deviasi, varian, maksimum, minimum, sum, range, kurtosis, dan skewness (Ghozali, 2005).

Tabel 1. Hasil Analisis Statistik Deskriptif

\begin{tabular}{llcccc}
\hline & $\mathrm{N}$ & Minimum & Maximum & Mean & Std. Deviation \\
\hline A & 110 & 2,8 & 4,0 & 3,430 & 0,3849 \\
B & 110 & 2,8 & 4,0 & 3,509 & 0,3789 \\
C & 110 & 2,3 & 4,0 & 3,455 & 0,3797 \\
D & 110 & 3,0 & 4,0 & 3,621 & 0,3478 \\
\hline
\end{tabular}

Sumber: Output SPSS, 2018

Tabel hasil analisis statistik deskriptif diatas menunjukkan bahwa:

1. Pemahaman kualitas laporan keuangan pemerintahan : Dari hasil output SPSS menunjukkan jumlah responden (N) 110, dari 110 responden nilai pemahaman kualitas laporan keuangan pemerintahan terkecil (minimum) adalah 2,8 dan nilai terbesar (maximum) adalah 4,0. Nilai rata-rata (mean) jawaban responden mengenai indikator pemahaman kualitas laporan keuangan pemerintahan adalah 3,430.Dari nilai rata-rata ini, menunjukkan bahwa Pemahaman kualitas laporan keuangan pemerintahan telah baik dan dirasakan manfaatnya. Standar deviasi pada indikator pemahaman kualitas laporan keuangan pemerintahan adalah sebesar 0,3849 yang menunjukkan jawaban responden bervariasi.

2. Tanggung Jawab Profesi : Dari hasil output SPSS menunjukkan jumlah responden (N) 110, dari 110 responden nilai tanggung jawab profesi terkecil (minimum) adalah 2,8 dan nilai terbesar (maximum) adalah 4,0. Nilai rata-rata (mean) jawaban responden mengenai indikator tanggung jawab profesi adalah 3,509Dari nilai rata-rata ini, menunjukkan bahwa 
indikator tanggung jawab profesi telah baik dan dirasakan manfaatnya. Standar deviasi pada indikator tanggung jawab profesi adalah sebesar 0,3789 yang menunjukkan jawaban responden bervariasi.

3. Integritas : Dari hasil output SPSS menunjukkan jumlah responden (N) 110, dari 110 responden nilai integritas (minimum) adalah 2,3 dan nilai terbesar (maximum) adalah 4,0. Nilai rata-rata (mean) jawaban responden mengenai indikator integritas adalah 3,455.Dari nilai rata-rata ini, menunjukkan bahwa akademisi dan praktisi paham dengan integritas yang ada pada auditor dalam memutuskan opini berdasarkan Standar Standar Akuntansi Pemerintahan. Deviasi pada indikator integritas adalah sebesar 0,3797 yang menunjukkan jawaban responden bervariasi.

4. Objektivitas : Dari hasil output SPSS menunjukkan jumlah responden (N) 110, dari 110 responden nilai indikator integritas terkecil (minimum) adalah 3,0 dan nilai terbesar (maximum) adalah 4,0. Nilai rata-rata (mean) jawaban responden mengenai indikator objektivitas adalah 3,621.Dari nilai rata-rata ini, menunjukkan bahwa pihak akademisi maupun praktisi mengerti akan objektivitas yang dimiliki oleh auditor dalam membuat keputusan untuk mengeluarkan opini audit. Standar deviasi pada indikator objektivitas adalah sebesar 0,3478 yang menunjukkan jawaban responden bervariasi.

\section{Uji Instrumen Penelitian}

\section{Uji Validitas}

Uji validitas dari indikator pemahaman kualitas laporan keuangan pemerintahan dinyatakan valid. Hasil uji validitas untuk indikator tanggung jawab profesi dinyatakan valid. Pada uji validitas untuk indikator integritas dinyatakan valid, dan uji validitas untuk indikator objektivitas dinyatakan valid.

\section{Uji Reliabilitas}

Dari uji reliabilitas dengan menggunakan SPSS maka dapat dilihat bahwa Cronbach's Alpha yaitu 0,814 lebih besar dari 0,60 (0,814>0,60). Hal tersebut menunjukkan indikator pemahaman kualitas laporan keuangan pemerintahan adalah reliabel. Nilai Cronbach's Alpha untuk indikator tanggung jawab profesidalam opini audit adalah lebih besar daripada 0,60 yaitu sebesar 0,804. Hal itu menunjukkan bahwa indikator tersebut adalah reliabel. Nilai Cronbach's Alpha lebih besar dari 0,60 yaitu sebesar 0,692. Hal itu menunjukkan bahwa indikator integritas adalah reliabel. Nilai Cronbach's Alpha dari indikator objektivitas adalah 0,611. Sesuai dengan ketentuan yang ada, maka indikator objektivitas dikatakan reliabel jika nilai Cronbach's Alpha $>0,60$.

\section{Uji Normalitas Data}

Uji normalitas dari penelitian ini dengan menggunakan SPSS, dijelaskan sebagai berikut:

1. Berdasarkan output test of normality, diperoleh nilai signifikansi untuk kelompok 1 sebesar 0,645, sedangkan nilai signifikansi untuk kelompok 2 sebesar 0,679. Karena nilai signifikansi kelompok 1 dan $2>0,05$, maka dapat disimpulkan bahwa data pemahaman kualitas laporan keuangan pemerintahan berdistribusi normal.

2. Berdasarkan output test of normality, diperoleh nilai signifikansi untuk kelompok 1 sebesar 0,724, sedangkan nilai signifikansi untuk kelompok 2 sebesar 0,751. Karena nilai signifikansi kelompok 1 dan $2>0,05$, maka dapat disimpulkan bahwa data pemahaman kualitas laporan keuangan pemerintahan berdistribusi normal.

3. Berdasarkan output test of normality, diperoleh nilai signifikansi untuk kelompok 1 sebesar 0,811, sedangkan nilai signifikansi untuk kelompok 2 sebesar 0,823. Karena nilai 
signifikansi kelompok 1 dan $2>0,05$, maka dapat disimpulkan bahwa data pemahaman kualitas laporan keuangan pemerintahan berdistribusi normal.

4. Berdasarkan output test of normality, diperoleh nilai signifikansi untuk kelompok 1 sebesar 0,589, sedangkan nilai signifikansi untuk kelompok 2 sebesar 0,633. Karena nilai signifikansi kelompok 1 dan $2>0,05$, maka dapat disimpulkan bahwa data pemahaman kualitas laporan keuangan pemerintahan berdistribusi normal.

\section{Uji Homogenitas}

Dalam statistik, uji homogenitas dihasilkan nilai signifikansi indikator pemahaman kualitas laporan keuangan pemerintahan sebesar 0,060>0,05, artinya data bersifat homogen atau memiliki varian yang sama. Nilai signifikansi indikator tanggung jawab profesi sebesar $0,053>0,05$, artinya data bersifat homogen atau memiliki varian yang sama. Nilai signifikansi indikator integritas sebesar 0,070>0,05, artinya data bersifat homogen atau memiliki varian yang sama. nilai signifikansi indikator objektivitas sebesar 0,062>0,05, artinya data bersifat homogen atau memiliki varian yang sama.

\section{Pengujian Hipotesis}

Langkah awal pengujian adalah melakukan uji dengan melihat pada kesamaan atau perbedaan nilai rata-rata jawaban responden. Setelah itu melihat pada kesamaan atau perbedaan nilai varian dan mean masing-masing reponden. Untuk menerima atau menolak hipotesis, mengacu pada kriteria yang telah di tentukan sebelumnya.

Tabel 2 Hasil Pengujian Hipotesis

\begin{tabular}{|c|c|c|c|c|c|c|c|}
\hline Hipotesis & Indikator & & $\begin{array}{c}\text { Koefisien } \\
\text { Regresi }\end{array}$ & $\begin{array}{c}\mathrm{F} \\
\text { hitung }\end{array}$ & ${ }^{\mathrm{t}}$ & sig & Ket \\
\hline \multirow{2}{*}{$\mathrm{Ha}_{1}$} & \multirow{2}{*}{$\begin{array}{l}\text { Pemahaman } \\
\text { Kualitas } \\
\text { Laporan } \\
\text { Keuangan } \\
\text { Pemerintahan }\end{array}$} & Praktisi & 180,0 & \multirow[t]{2}{*}{6,904} & 0,072 & \multirow[t]{2}{*}{0,072} & Tidak \\
\hline & & Akademisi & 197,1 & & 0,068 & & $\begin{array}{l}\text { terdapat } \\
\text { perbedaan } \\
\text { signifikan }\end{array}$ \\
\hline \multirow[t]{2}{*}{$\mathrm{Ha}_{2}$} & Tanggung & Praktisi & 188,4 & \multirow[t]{2}{*}{5,337} & 0,020 & \multirow[t]{2}{*}{0,023} & terdapat \\
\hline & Jawab Profesi & Akademisi & 197,6 & & 0,020 & & $\begin{array}{l}\text { perbedaan } \\
\text { siginifikan }\end{array}$ \\
\hline \multirow[t]{2}{*}{$\mathrm{Ha}_{3}$} & Integritas & Praktisi & 181,3 & \multirow[t]{2}{*}{62,004} & 0,000 & \multirow[t]{2}{*}{0,067} & tidak \\
\hline & & Akademisi & 182,8 & & 0,000 & & $\begin{array}{l}\text { terdapat } \\
\text { perbedaan } \\
\text { siginifikan }\end{array}$ \\
\hline \multirow[t]{2}{*}{$\mathrm{Ha}_{4}$} & Objektivitas & Praktisi & 205,0 & \multirow[t]{2}{*}{48,423} & 0,000 & \multirow[t]{2}{*}{0,071} & tidak \\
\hline & & Akademisi & 191,3 & & 0,000 & & $\begin{array}{l}\text { terdapat } \\
\text { perbedaan } \\
\text { siginifikan }\end{array}$ \\
\hline
\end{tabular}

Sumber: Output SPSS, 2018

Pembahasan uji hipotesis penelitian dari tabel 2 diatas adalah:

Ha1: Terdapat perbedaan persepsi antara akademisi dengan praktisi terhadap opini audit tentang pemahaman kualitas laporan keuangan pemerintahan. rata-rata jawaban pada pemahaman kualitas laporan keuangan pemerintahan untuk responden akademisi adalah 197,1. 
sedangkan untuk responden praktisi adalah 180,0. Secara absolut jelas bahwa rata-rata pada pemahaman kualitas laporan keuangan pemerintahan berbeda antara responden akademisi dengan responden praktisi. Nilai $\mathrm{F}$ hitung levene test untuk pemahaman kualitas laporan keuangan pemerintahan adalah sebesar 6,904 dengan probabilitas sebesar 0,00 . Oleh karena probabilitasnya sebesar $0,00<0,05$, maka dapat disimpulkan bahwa kedua varian adalah tidak sama sehingga menggunakan asumsi equal variances not assumed. Oleh karena variannya tidak sama, maka analisis uji beda t-testnya harus menggunakan asumsi equal variances not assumed sebesar sebesar -0,055 dengan probabilitas signifikansi sebesar 0,072 (two tail). Jadi untuk kemampuan analisis deduktif, oleh karena probabilitasnya sebesar 0,072 >0,05, maka dapat disimpulkan bahwa secara statistik kedua rata-rata (mean) tidak terdapat perbedaan siginifikan antara responden akademisi dengan responden praktisi.

Ha2: Terdapat perbedaan persepsi antara akademisi dengan praktisi terhadap opini audit tentang tanggung jawab profesi. rata-rata jawaban pada tanggung jawab profesiuntuk responden akademisi adalah 197,6. sedangkan untuk responden praktisi adalah 188,4. Secara absolut jelas bahwa rata-rata pada pemahaman kualitas laporan keuangan pemerintahan berbeda antara responden akademisi dengan responden praktisi. Nilai Fhitung levene test untuk tanggung jawab profesiadalah sebesar 5,337dengan probabilitas sebesar 0,00. Oleh karena probabilitasnya sebesar $0,00<0,05$, maka dapat disimpulkan bahwa kedua varian adalah tidak sama sehingga menggunakan asumsi equal variances not assumed. Oleh karena variannya tidak sama, maka analisis uji beda t-testnya harus menggunakan asumsi equal variances not assumed sebesar sebesar -0,055 dengan probabilitas signifikansi sebesar 0,023 (two tail). Jadi untuk kemampuan analisis deduktif, oleh karena probabilitasnya sebesar $0,023<0,05$, maka dapat disimpulkan bahwa secara statistik kedua rata-rata (mean) terdapat perbedaan siginifikan antara responden akademisi dengan responden praktisi.

Ha3: Terdapat perbedaan persepsi antara akademisi dengan praktisi terhadap opini audit tentang integritas. rata-rata jawaban pada indikator integritas untuk responden akademisi adalah 182,8 . sedangkan untuk responden praktisi adalah 181,3. Secara absolut jelas bahwa ratarata pada indikator integritas tidak jauh berbeda antara responden akademisi dengan responden praktisi. Nilai Fhitung levene test untuk pemahaman kualitas laporan keuangan pemerintahan adalah sebesar 62,004dengan probabilitas sebesar 0,00. Oleh karena probabilitasnya sebesar $0,00<0,05$, maka dapat disimpulkan bahwa kedua varian adalah tidak sama sehingga menggunakan asumsi equal variances not assumed. Oleh karena variannya tidak sama, maka analisis uji beda t-testnya harus menggunakan asumsi equal variances not assumed sebesar sebesar -0,055 dengan probabilitas signifikansi sebesar 0,062 (two tail). Jadi untuk kemampuan analisis deduktif, oleh karena probabilitasnya sebesar 0,067>0,05, maka dapat disimpulkan bahwa secara statistik kedua rata-rata (mean) tidak terdapat perbedaan siginifikan antara responden akademisi dengan responden praktisi.

Ha4: Terdapat perbedaan persepsi antara akademisi dengan praktisi terhadap opini audit tentang objektivitas. rata-rata jawaban pada indikator objektivitas untuk responden akademisi adalah 191,3. sedangkan untuk responden praktisi adalah 205,0. Secara absolut jelas bahwa rata-rata pada indikator objektivitas berbeda antara responden akademisi dengan responden praktisi. Nilai Fhitung levene test untuk indikator objektivitas adalah sebesar 48,423dengan probabilitas sebesar 0,00. Oleh karena probabilitasnya sebesar $0,00<0,05$, maka dapat disimpulkan bahwa kedua varian adalah tidak sama sehingga menggunakan 
asumsi equal variances not assumed. Oleh karena variannya tidak sama, maka analisis uji beda t-testnya harus menggunakan asumsi equal variances not assumed sebesar sebesar -0,055 dengan probabilitas signifikansi sebesar 0,071 (two tail). Jadi untuk kemampuan analisis deduktif, oleh karena probabilitasnya sebesar 0,071>0,05, maka dapat disimpulkan bahwa secara statistik kedua rata-rata (mean) tidak terdapat perbedaan siginifikan antara responden akademisi dengan responden praktisi.

\section{PENUTUP}

Berdasarkan hasil analisis data dan pengujian hipotesis, maka ditarik kesimpulan sebagai berikut:

1. Berdasarkan hasil pengujian hipotesis dan deskriptif jawaban responden, maka disimpulkan bahwa tidak terdapat perbedaan signifikan rata-rata antara akademisi dengan praktisi terhadap pemahaman kualitas laporan keuangan pemerintahan. Maka dari itu pihak akademisi dan praktisi tidak memiliki tingkat pemahaman dan pengetahuan yang berbeda.

2. Hasil pengujian hipotesis dan deskriptif jawaban responden, maka kesimpulannya bahwa hasil uji hipotesis terbukti terdapat perbedaan persepsi yang signifikan rata-rata terhadap tanggung jawab profesi antara akademisi dengan praktisi mempunyai Akan tetapi konsisten dengan teori atribusi dan pemersepsian yang berdasarkan dengan pandangan dan pengalaman yang berbeda. Maka dari itu pihak akademisi dan praktisi memiliki tingkat pemahaman dan pengetahuan yang berbeda.

3. Pada indikator Integritas terbukti bahwa tidak terdapat perbedaan signifikan, maka dapat disimpulkan bahwa akademisi dan praktisi memiliki tingkat pengetahuan dan pemahaman yang sama terhadap indikator integritas.

4. Pada indikator Objektivitas terbukti bahwa tidak terdapat perbedaan signifikan. Maka dapat disimpulkan bahwa akademisi dan praktisi memiliki tingkat pengetahuan dan pemahaman yang sama tentang objektivitas auditor dalam menetapkan opini audit.

\section{Implikasi hasil penelitian}

Hasil penelitian ini diharapkan dapat memberikan memberikan kontribusi bagi para pengajar dalam mengembangkan pemahaman tentang opini audit, dan memberikan kontribusi bagi literatur tentang persepsi akademisi dan praktisi terhadap opini audit berdasarkan laporan keuangan pemerintahan melalui beberapa cara, antara lain: dengan membuka wawasan tentang semakin pentingnya pemahaman audit serta dalam pengembangan ilmu audit agar dapat memberikan pemahaman yang lebih baik mengenai pemahaman audit pada sektor pemerintahan.

\section{Keterbatasan}

Dalam penelitian ini terdapat beberapa keterbatasan. Keterbatasan ini perlu diperhatikan pada penelitian serupa selanjutnya. Keterbatasan tersebut antara lain:

a. Penelitian ini hanya membedakan persepsi akademisi hanya akuntan pendidik pada universitas di Palembang sedangkan praktisi belum keseluruhan dari jenis pekerjaan tersebarkan dan tidak membedakan persepsi kelompok responden secara spesifikasi praktisi lainya seperti akuntan manajemen dan akuntan publik.

b. Penelitian ini hanya dilakukan di kota Palembang sehingga tidak dapat digeneralisasikan di seluruh indonesia. 


\section{DAFTAR PUSTAKA}

Ardelean, A. (2013). Auditors' Ethics And Their Impact On Public Trust. Procedia - Social And Behavioral Sciences, 92(Lumen), 55-60. Https://Doi.Org/10.1016/J.Sbspro.2013.08.637

Arens, A. A., Elder, R. J., \& Beasley, M. S. (2012). Auditing And Assurance Services. Orbit An International Journal On Orbital Disorders And Facial Reconstructive Surgery. Https://Doi.Org/10.1016/0005-1098(86)90018-X

Astuti, B. D. N. W., \& Latrini, M. Y. (2017). Kecerdasan Emosional Sebagai Pemoderasi Pengaruh Kompentensi Dan Independensi Pada Kinerja Auditor. Akuntansi Universitas Udayana, 21(2), 1052-1071.

Badan Pemeriksa Keuangan Republik Indonesia. (2007). Peraturan Badan Pemeriksa Keuangan Republik Indonesia No.1 Tahun 2017 Standar Pemeriksaan Keuangan Negara. Peraturan Badan Pemeriksa Keuangan Republik Indonesia No.1 Tahun 2017 Standar Pemeriksaan Keuangan Negara.

Barrainkua, I., \& Espinosa-Pike, M. (2018). The Influence Of Auditors' Professionalism On Ethical Judgement: Differences Among Practitioners And Postgraduate Students. Revista De Contabilidad, 21(2), 176-187. Https://Doi.Org/10.1016/J.Rcsar.2017.07.001

BPK. (2018). Ikhtisar Hasil Pemeriksaan Semester 1 Tahun 2018.

Cao, L., Li, W., \& Zhang, L. (2015). Audit Mode Change, Corporate Governance And Audit Effort. China Journal Of Accounting Research, 8(4), 315-335. Https://Doi.Org/10.1016/J.Cjar.2015.05.002

Dobre, E., Turlea, C., \& Turlea, E. (2015). The Influence Of Post Crisis Corporate Governance Practices Upon Financial Audit. Procedia Economics And Finance, 32(15), 1100-1106. Https://Doi.Org/10.1016/S2212-5671(15)01574-9

Gonzalo-Angulo, J. A., \& Garvey, A. M. (2018). Audit Research: Some Reflections. Revista De Contabilidad, 21(2), 107-115. Https://Doi.Org/10.1016/J.Rcsar.2018.05.004

Hilmi, A. Z., \& Martani, D. (2012). Analisis Faktor-Faktor Yang Mempengaruhi Tingkat Pengungkapan Laporan Keuangan Pemerintah Provinsi. In Simposium Nasional Akuntansi $X v$ (Pp. 1-26).

Hudayati, A. (2002). Perkembangan Penelitian Akuntansi Keperilakuan: Berbagai Teori Dan Pendekatan Yang Melandasi. Jaai, 6(2), 81-96.

Husen, S. R. (2017). Persepsi Akademisi, Praktisi, Dan Mahasiswa Akuntansi Terhadap Keahlian Akuntan Forensik Di Makassar. Wira Ekonomi Mikroskil, 7(April).

Iprianto. (2012). Persepsi Akademisi Dan Praktisi Akuntansi Terhadap Keahlian Akuntan Forensik. Retrieved From Http://Ejournal-S1.Undip.Ac.Id

Lino, A. F., \& Aquino, A. C. B. De. (2017). The Diversity Of The Brazilian Regional Audit Courts On Government Auditing. Revista Contabilidade \& Finanças, 29(76), 26-40. Https://Doi.Org/10.1590/1808-057x201803640

Liu, J., \& Lin, B. (2012). Government Auditing And Corruption Control: Evidence From 
PERSEPSI AKADEMISI DAN PRAKTISI TERHADAP OPINI HASIL PEMERIKSAAN AUDIT LAPORAN KEUANGAN PADA LEMBAGA PEMERINTAHAN DI INDONESIA

Bunga Aulia, Rika Henda Safitri, dan Rina Tjanikirana

China's Provincial Panel Data. China Journal Of Accounting Research, 5(2), 163-186. Https://Doi.Org/10.1016/J.Cjar.2012.01.002

Marfiana, N., \& Kurniasih, L. (2013). Pemeriksaan Audit Bpk Terhadap Kinerja Keuangan Pemerintah Daerah Kabupaten / Kota. Journal \& Proceeding Universitas Jenderal Soedirman, 3(1), 1-16.

Muhammad, R. (2008). Persepsi Akuntan Dan Mahasiswa Yogyakarta Terhadap Etika Bisnis. Urnal Penelitian \& Pengabdian Dppm.Uii.Ac.Id, 6 No 1, 1-15.

Mulyanti, E. (2013). Persepsi Akademisi Universitas Sumatera Utara Terhadap Adanya Akuntansi Forensik. Jurnal Bisnis Administrasi, 02 No 2(2009), 70-75.

Navallas, B., Del Campo, C., \& Camacho-Miñano, M. Del M. (2017). Exploración De Los Estereotipos De Los Auditores: La Perspectiva De Los Estudiantes Universitarios. Revista De Contabilidad, 20(1), 25-35. Https://Doi.Org/10.1016/J.Rcsar.2015.11.001

Putra, M. A. (2015). Perbedaan Persepsi Akademisi Dan Praktisi Akuntansi Tentang Akuntansi Forensik Sebagai Mata Kuliah. Ekbis: Jurnal Ekonomi Dan Bisnis, 2, 1-21.

Rahmina, L. Y., \& Agoes, S. (2014). Influence Of Auditor Independence, Audit Tenure, And Audit Fee On Audit Quality Of Members Of Capital Market Accountant Forum In Indonesia. Procedia - Social And Behavioral Sciences, 164(August), 324-331. Https://Doi.Org/10.1016/J.Sbspro.2014.11.083

Ramadhony, R., \& Hadiprajitno, P. B. (2014). Terhadap Kesenjangan Persepsi Audit Pemerintahan. Diponegoro Journal Of Accounting, 3 No 4, 1-13.

Safitri, R. H., \& Aulia, B. (2017). Analisis Faktor Yang Mempengaruhi Penentuan Opini Pada Lkpd Sumsel Berdasarkan Penerapan Sap. Jurnal Teori Dan Riset Administrasi Publik, 1(1), 120-128.

Setyaningrum, D., \& Syafitri, F. (2012). Analisis Pengaruh Karakteristik Pemerintah Daerah Terhadap Tingkat Pengungkapan Laporan Keuangan. Jurnal Akuntansi Dan Keuangan Indonesia, 9(2), 154-170. Https://Doi.Org/Http://Dx.Doi.Org/10.21002/Jaki.2012.10

Sutedja, C. (2003). Faktor-Faktor Yang Berpengaruh Terhadap Pemberian Opini Audit Going Concern Pada Perusahaan Manufaktur. Jurnal Akuntansi Kontemporer, 2(2), 153-170.

Thoyibatun, S. (2012). Faktor-Faktor Yang Berpengaruh Terhadap Perilaku Tidak Etis Dan Kecenderungan Kecurangan Akuntansi Serta Akibatnya Terhadap Kinerja Organisasi. Jurnal Ekonomi Dan Keuangan, 16(110), 245-260.

Unnisa, I. A. (2015). Faktor-Faktor Yang Mempengaruhi Auditor Dalam Pemberian Opini Audit Atas Laporan Keuangan (Studi Pada Auditor Di Bpk Perwakilan Provinsi Riau). Jom Fekon, 2 No 2, 1-15.

Utama, I. G. B. R. (2016). Teknik Sampling Dan Penentuan Jumlah Sampel. Universitas Dhyana Pura, Bali. Https://Doi.Org/10.13140/Rg.2.1.5187.0808

Wu, X. (2012). Corporate Governance And Audit Fees: Evidence From Companies Listed On The Shanghai Stock Exchange. China Journal Of Accounting Research, 5(4), 321-342. Https://Doi.Org/10.1016/J.Cjar.2012.10.001 